\title{
A Fe-N-C catalyst with highly dispersed iron in carbon for oxygen reduction reaction and its application in direct methanol fuel cells
}

\author{
Lingzheng $\mathrm{Gu}^{\mathrm{a}, \mathrm{c}}$, Luhua Jiang a,*, Xuning Li b,c, Jutao Jin a, Junhu Wang b, Gongquan Sun a,\# \\ a Division of Fuel Cell \& Battery, Dalian National Laboratory for Clean Energy, Dalian Institute of Chemical Physics, Chinese Academy of Sciences, Dalian \\ 116023, Liaoning, China \\ b Mössbauer Effect Data Center, Dalian Institute of Chemical Physics, Chinese Academy of Sciences, Dalian 116023, Liaoning, China \\ c University of Chinese Academy of Sciences, Beijing 100049, China
}

\section{A R T I C L E I N F O}

\section{Article history:}

Received 7 January 2016

Accepted 29 January 2016

Published 5 April 2016

Keywords:

Highly dispersed iron

Microporous carbon

Oxygen reduction reaction

Direct methanol fuel cell

\begin{abstract}
A B S T R A C T
Exploring non-precious metal catalysts for the oxygen reduction reaction (ORR) is essential for fuel cells and metal-air batteries. Herein, we report a Fe-N-C catalyst possessing a high specific surface area $\left(1501 \mathrm{~m}^{2} / \mathrm{g}\right)$ and uniformly dispersed iron within a carbon matrix prepared via a two-step pyrolysis process. The Fe-N-C catalyst exhibits excellent ORR activity in $0.1 \mathrm{~mol} / \mathrm{L} \mathrm{NaOH}$ electrolyte (onset potential, $E_{0}=1.08 \mathrm{~V}$ and half wave potential, $E_{1 / 2}=0.88 \mathrm{~V}$ vs. reversible hydrogen electrode) and $0.1 \mathrm{~mol} / \mathrm{L} \mathrm{HClO}_{4}$ electrolyte $\left(E_{0}=0.85 \mathrm{~V}\right.$ and $E_{1 / 2}=0.75 \mathrm{~V}$ vs. reversible hydrogen electrode). The direct methanol fuel cells employing Fe- $\mathrm{N}-\mathrm{C}$ as the cathodic catalyst displayed promising performance with a maximum power density of $33 \mathrm{~mW} / \mathrm{cm}^{2}$ in alkaline media and $47 \mathrm{~mW} / \mathrm{cm}^{2}$ in acidic media. The detailed investigation on the composition-structure-performance relationship by X-ray diffraction, X-ray photoelectron spectroscopy and Mössbauer spectroscopy suggests that Fe- $\mathrm{N}_{4}$, together with graphitic- $\mathrm{N}$ and pyridinic- $\mathrm{N}$ are the active ORR components. The promising direct methanol fuel cell performance displayed by the Fe-N-C catalyst is related to the intrinsic high catalytic activity, and critically for this application, to the high methanol tolerance.
\end{abstract}

(C) 2016, Dalian Institute of Chemical Physics, Chinese Academy of Sciences. Published by Elsevier B.V. All rights reserved.

\section{Introduction}

The oxygen reduction reaction (ORR) is the cathodic reaction of energy sources such as fuel cells and metal-air batteries. The slow kinetics of the ORR hinders the performance of such energy-related technologies. Presently, Pt and its alloys set the benchmark for ORR, being the most active catalysts, however, the limited reserves and the high cost of Pt limits commercialization of the above power sources. The pursuit of highly efficient and low-cost electrocatalysts to replace current expensive
Pt catalysts for ORR applications has attracted a wealth of scientific interest for several decades [1-6].

Since cobalt phthalocyanine was observed to catalyze the ORR in 1964 [2], significant effort has been devoted to the synthesis of non-precious metal catalysts $[3,7]$. In particular, iron-based catalysts, synthesized by the pyrolysis of precursors composed of nitrogen, carbon and iron, have attracted extensive attention owing to their promising ORR activity. Previous studies have shown that the ORR activity of iron-based catalysts strongly depends on the synthesis procedure and the

\footnotetext{
* Corresponding author. Tel/Fax: +86-411-84379063; E-mail: sunshine@dicp.ac.cn

\# Corresponding author. Tel/Fax: +86-411-84379063; E-mail: gqsun@dicp.ac.cn

This work was supported by the "Strategic Priority Research Program" of the Chinese Academy of Sciences (XDA09030104), the National Basic Research Program of China (973 Program, 2012CB215500), and the National Natural Science Foundation of China $(21576258,50823008)$. DOI: 10.1016/S1872-2067(15)61049-X | http://www.sciencedirect.com/science/journal/18722067 | Chin. J. Catal., Vol. 37, No. 4, April 2016
} 
precursor nature, which may influence the chemical states of iron and nitrogen heteroatoms and also the textural structure of the catalysts [8].

Conventional one-pot pyrolysis processes typically generate a low abundance of active sites, as when thermally activated Fe atoms are prone to agglomerate into large particles at high temperatures. To disperse iron uniformly in the host, various strategies, including ball-milling [3], wet-impregnation and ion exchange [9] have been extensively adopted. Recently, a spatial confinement strategy was proposed to synthesize various materials, including ultrafine metals and alloys where growth was restricted within two or three dimensional confined environments. The principal function is to confine the diffusion of atoms or the growth of particles to a limited space, thus producing unique characteristics in morphology, composition and/or microstructure [10,11].

Herein, we synthesized a Fe-N-C catalyst via a two-step pyrolysis process as illustrated in Scheme 1 . The first step generates a nitrogen-doped carbon of high specific surface area $\left(1227 \mathrm{~m}^{2} / \mathrm{g}\right)$ by the pyrolysis of polypyrrole (PPy) and ethylenediaminetetraacetic acid disodium salt (EDTA-2Na). The second step uses the formed intermediate as a host to anchor iron producing a carbon matrix containing highly dispersed iron. The obtained Fe-N-C catalyst displays superior ORR activity in both alkaline and acid solutions. Furthermore, the methanol tolerance property of the Fe-N-C catalyst is critical in its advantage over the $\mathrm{Pt} / \mathrm{C}$ catalyst for direct methanol fuel cells (DMFCs) as the Fe-N-C catalyst circumvents problems related to intractable methanol crossover. The DMFCs fabricated employing the $\mathrm{Fe}-\mathrm{N}-\mathrm{C}$ catalyst as the cathode display promising discharging performance.

\section{Experimental}

\subsection{Synthesis of materials}

The N-C catalyst was derived from PPy, which was obtained by polymerization of pyrrole. Briefly, $25 \mathrm{~g}$ cetyltrimethylammonium bromide (CTAB, $\mathrm{C}_{19} \mathrm{H}_{42} \mathrm{BrN}$, Tianjin Guangfu Fine Chemical Research Institute) was dispersed in $80 \mathrm{~mL}$ ethylene glycol (EG, Tianjin Kemiou Chemical Reagent Co., Ltd.)

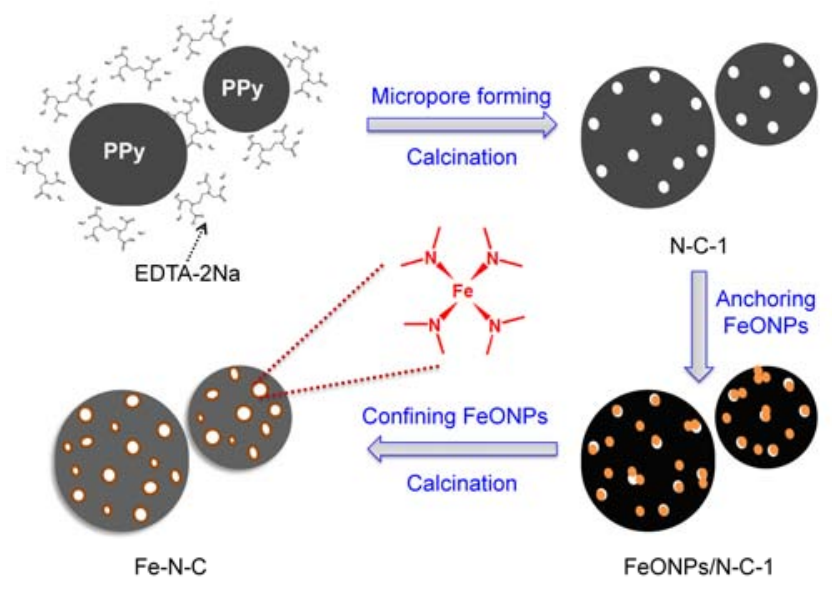

Scheme 1. Schematic diagram of the Fe-N-C catalyst synthesis route. followed by the addition of $6 \mathrm{~mL}$ pyrrole monomer $\left(\mathrm{C}_{4} \mathrm{H}_{5} \mathrm{~N}\right.$, Sinopharm Chemical Reagent Co., Ltd.). After stirring for $1 \mathrm{~h}, 40$ mL EG containing $12 \mathrm{~g} \mathrm{FeCl}_{3} \cdot 6 \mathrm{H}_{2} \mathrm{O}$ was added dropwise with stirring. The polymerization process continued for $5 \mathrm{~h}$ before $200 \mathrm{~mL}$ methanol $\left(\mathrm{CH}_{3} \mathrm{OH}\right.$, Xilong Chemical Co., Ltd.) was added and stirred overnight. The obtained black ink was then filtered, washed with water multiple times and dried in an oven at $80^{\circ} \mathrm{C}$ for $8 \mathrm{~h}$ to obtain PPy. The obtained PPy was thermally treated under a $\mathrm{N}_{2}$ atmosphere at $800{ }^{\circ} \mathrm{C}$ for $1 \mathrm{~h}$ to obtain the black powder, denoted as N-C.

The above PPy was blended with EDTA-2Na $\left(\mathrm{C}_{10} \mathrm{H}_{14} \mathrm{~N}_{2} \mathrm{O}_{8} \mathrm{Na}_{2} \cdot 2 \mathrm{H}_{2} \mathrm{O}\right.$, Tianda Chemical Reagent Co., Ltd.) at a mass ratio of 1:2 in deionized water under vigorous stirring for $3 \mathrm{~h}$, followed by evaporating the deionized water at $70{ }^{\circ} \mathrm{C}$ before drying at $80{ }^{\circ} \mathrm{C}$. After grinding, the powder was thermally treated at $800{ }^{\circ} \mathrm{C}$ for $1 \mathrm{~h}$ under a $\mathrm{N}_{2}$ atmosphere. Thereafter, the sample was sonicated in $1 \mathrm{~mol} / \mathrm{L} \mathrm{HCl}$ for $\sim 2 \mathrm{~h}$, washed with distilled water multiple times and dried in an oven at $80{ }^{\circ} \mathrm{C}$ overnight to obtain N-C-1.

$\mathrm{FeCl}_{3}$ was hydrolyzed in an ethanol solution containing ammonia to obtain an iron oxide colloid (denoted as FeONPs), which was added to $\mathrm{N}-\mathrm{C}-1$ followed by thermal treatment to obtain the Fe-N-C sample. Briefly, a 0.2-mmol $\mathrm{FeCl}_{3} /$ ethanol solution and $2 \mathrm{~mL} 30 \% \mathrm{NH}_{3} \cdot \mathrm{H}_{2} \mathrm{O}$ was added into $100 \mathrm{~mL}$ ethanol in a flask. The mixture was stirred and refluxed at $100{ }^{\circ} \mathrm{C}$ for $1 \mathrm{~h}$. Subsequently, $200 \mathrm{mg} \mathrm{N}-\mathrm{C}-1$ was added and stirred for $4 \mathrm{~h}$. Thereafter the solvent was evaporated using a rotary evaporator to obtain a black powder, which was then dried in an oven at $80^{\circ} \mathrm{C}$ overnight. The obtained sample was pyrolyzed at $900{ }^{\circ} \mathrm{C}$ for $1 \mathrm{~h}$ under $\mathrm{N}_{2}$ to obtain a loose and black powder, denoted as Fe-N-C.

$\mathrm{N}-\mathrm{C}-2$ was prepared for comparison with the Fe-N-C catalyst to discriminate the role of iron after the second thermal treatment. The N-C- 1 was thermally treated in the absence of Fe at $900{ }^{\circ} \mathrm{C}$ for $1 \mathrm{~h}$ under a $\mathrm{N}_{2}$ atmosphere.

\subsection{Physical characterization}

A scanning electron microscope (SEM, JSM-7800F) was used to study particle morphology, and energy-dispersive x-ray spectroscopy (EDX) was recorded on a specific area of the electrocatalyst. A transmission electron microscope (TEM, JEM-2100) was used to study the crystal nature of the electrocatalyst employing an acceleration voltage of $200 \mathrm{kV}$. The high resolution TEM (HRTEM) micrograph was obtained on a TEM (JEM-2100F) using an acceleration voltage of $200 \mathrm{kV}$. X-ray diffraction (XRD) studies were performed on a Rigaku X-2000 diffractometer using $\mathrm{Cu} K \alpha$ radiation with a Ni filter. The samples were scanned at a rate of $5 \% \mathrm{~min}$. The chemical composition of the four electrocatalysts were characterized by X-ray photoelectron spectroscopy (XPS) measurements (ESCALAB 250Xi) using Al $K_{\alpha}$ radiation.

$\mathrm{Ar}$ isotherms at $-186{ }^{\circ} \mathrm{C}$ were measured using a Quantachrome Autosorb-iQ instrument. Before analysis, samples were outgassed at $180{ }^{\circ} \mathrm{C}$ under vacuum for $4 \mathrm{~h}$. The Brunauer-Emmett-Teller (BET) surface area and pore size distribution was calculated by the non-linear density-functional theory 
(NLDFT).

Room temperature ${ }^{57} \mathrm{Fe}$ Mössbauer spectroscopy was used to investigate the oxidation state and coordination environment of iron ions in the Fe-N complexes. A ${ }^{57} \mathrm{Co}(\mathrm{Rh})$ source, moving with a constant acceleration mode, was used as the $\gamma$-radiation source. The velocity was calibrated by a standard $\alpha$-iron foil. The spectra were fitted with the appropriate Lorentzian line superpositions using the MossWinn 3.0i computer program. In this way, the ${ }^{57} \mathrm{Fe}$ Mössbauer spectral parameters could be determined, including the isomer shift (IS), the electric quadrupole splitting $(Q S)$, the full width at half maximum, the hyperfine field $\left(\mathrm{H}_{\mathrm{hf}}\right)$ and the relative resonance areas of the different components of the absorption patterns.

\subsection{Electrochemical measurements}

Rotating disk electrode (RDE) and rotating ring disc electrode (RRDE) measurements were conducted in a three-electrode cell setup with a computer-controlled bipotentiostat (Pine Company). The reference electrode was an $\mathrm{Hg} / \mathrm{HgO}$ electrode (MMO) in $0.1 \mathrm{~mol} / \mathrm{L} \mathrm{NaOH}$ solution with respect to an alkaline electrolyte, and a standard calomel electrode (SCE) with a vacuum tube voltmeter for acidic electrolytes. The counter electrode was Pt wire. The MMO and SCE reference electrode were calibrated and the potential converted into reversible hydrogen electrode (RHE) in this study. To prepare the working electrode, $2.5 \mathrm{mg}$ of catalyst powder was dispersed in $1 \mathrm{~mL}$ of ethanol and $25 \mu \mathrm{L}$ of Nafion ${ }^{\circledR}$ solution $(5$ wt $\%$, DuPont). The suspension was then sonicated for $15 \mathrm{~min}$ to form a homogeneous ink, thereafter, the ink was pipetted onto the surface of a glassy carbon disc ( $\varnothing 5.7 \mathrm{~mm}$ for RRDE and $\varnothing 5.0 \mathrm{~mm}$ for RDE). The Fe-N-C loading was $0.62 \mathrm{mg} / \mathrm{cm}^{2}$ and the Pt/C loading (20 wt\% Pt/C, Johnson Matthey, JM) was 50 $\mu \mathrm{g} / \mathrm{cm}^{2}$.

For RRDE with the polycrystalline Pt biased at $1.23 \mathrm{~V}$ (vs. RHE), the working electrode surface was first electrochemically cleaned by cycling from $0.11-1.23 \mathrm{~V}$ (vs. RHE) for 20 cycles with a scan rate of $100 \mathrm{mV} / \mathrm{s}$. The background cyclic voltammogram (CV) was then collected at a scan rate of $10 \mathrm{mV} / \mathrm{s}$ in a $\mathrm{N}_{2}$-saturated $0.1 \mathrm{~mol} / \mathrm{L} \mathrm{NaOH}$ electrolyte. The RRDE measurement was performed in an $\mathrm{O}_{2}$-saturated $0.1 \mathrm{~mol} / \mathrm{L} \mathrm{NaOH}$ elec- trolyte at a scan rate of $10 \mathrm{mV} / \mathrm{s}$ at $1600 \mathrm{r} / \mathrm{min}$. The electron transfer number $(n)$ is calculated according to Eq. (1).

$$
n=4 I_{d} /\left(I_{d}+I_{r} / N\right)
$$

where $I_{\mathrm{r}}$ is the ring current, $I_{\mathrm{d}}$ is the disc current, and $N$ is the collection efficiency for $\mathrm{H}_{2} \mathrm{O}_{2}$ by the RRDE (0.38) [12].

The accelerated aging test (AAT) was performed in an $\mathrm{O}_{2}$-saturated $0.1 \mathrm{~mol} / \mathrm{L} \mathrm{NaOH}$ electrolyte scanning in the range of $0.60-1.00 \mathrm{~V}$ (vs. RHE) with a scan rate of $100 \mathrm{mV} / \mathrm{s}$. The background CVs and the ORR polarization curves were recorded every 1000 potential cycles during the AAT.

With respect to an acidic electrolyte, the RDE measurements of Fe-N-C and $20 \mathrm{wt} \% \mathrm{Pt} / \mathrm{C}$ (JM) electrocatalysts were conducted from $0.10-1.20 \mathrm{~V}$ (vs. RHE) at a scan rate of $10 \mathrm{mV} / \mathrm{s}$ at $1600 \mathrm{r} / \mathrm{min}$.

\subsection{Fabrication of DMFCs and single cell tests}

To obtain a membrane electrode assembly (MEA), the cathode and anode catalyst ink were painted directly on either side of the electrolyte membrane. The cathode was Fe- $\mathrm{N}-\mathrm{C}$ or 20 wt $\%$ Pt/C (JM). The anode was PtRu black catalysts (JM). The catalyst inks were prepared by dispersing the catalyst into appropriate amounts of ethanol and a $5 \% \mathrm{Nafion}^{\circledR}$ solution. A Nafion ${ }^{\circledR} 212$ membrane (DuPont) and an anion-exchange membrane (Tokuyama) were used to fabricate acidic and alkaline DMFCs, respectively. The MEA and the diffusion carbon layers were hot pressed at $120^{\circ} \mathrm{C}$ under a pressure of 500 pounds for $90 \mathrm{~s}$. The active area of the MEA was $1 \mathrm{~cm}^{2}$. The single cell was operated at $80^{\circ} \mathrm{C}$. The fuel used was $1 \mathrm{~mol} / \mathrm{L}$ $\mathrm{CH}_{3} \mathrm{OH}$ at the flow rate of $1 \mathrm{~mL} / \mathrm{min}$ for the acidic fuel cell, and $2 \mathrm{~mol} / \mathrm{L} \mathrm{CH}_{3} \mathrm{OH}$ in $1 \mathrm{~mol} / \mathrm{L} \mathrm{NaOH}$ at the flow rate of $2 \mathrm{~mL} / \mathrm{min}$ for the alkaline fuel cell.

\section{Results and discussion}

To characterize the synthesis process of the Fe- $\mathrm{N}-\mathrm{C}$ catalyst, the Ar adsorption-desorption isotherms of $\mathrm{N}-\mathrm{C}, \mathrm{N}-\mathrm{C}-1, \mathrm{~N}-\mathrm{C}-2$, FeONPs/N-C-1 and Fe-N-C (Fig. 1(a)) were analyzed. The pore size distribution curves are depicted in Fig. 1(b), and the relevant data summarized in Table 1 . For sample N-C-1, the isotherm presented a typical type-I behavior, with a steep increase
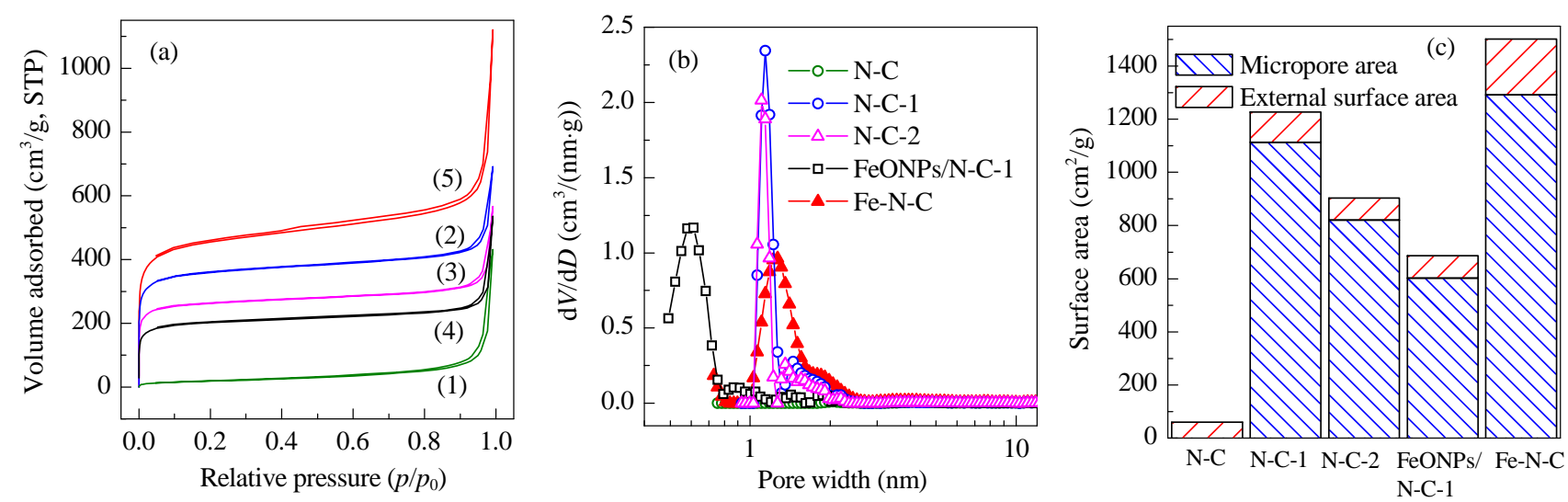

Fig. 1. (a) Ar adsorption-desorption isotherms, (b) the corresponding pore size distribution curves, and (c) the relative quantity of micropore area and external surface area for the electrocatalysts. (1) N-C; (2) N-C-1; (3) N-C-2; (4) FeONPs/N-C-1; (5) Fe-N-C. 
Table 1

Electrocatalyst textural parameters characterized by Ar adsorptiondesorption measurements.

\begin{tabular}{lcccc}
\hline Catalyst & $\begin{array}{c}\text { BET surface } \\
\text { area } \\
\left(\mathrm{m}^{2} / \mathrm{g}\right)\end{array}$ & $\begin{array}{c}\text { Micropore } \\
\text { surface area } \\
\left(\mathrm{m}^{2} / \mathrm{g}\right)\end{array}$ & $\begin{array}{c}\text { External } \\
\text { surface area } \\
\left(\mathrm{m}^{2} / \mathrm{g}\right)\end{array}$ & $\begin{array}{c}\text { Pore } \\
\text { width } \\
(\mathrm{nm})\end{array}$ \\
\hline $\mathrm{N}-\mathrm{C}$ & 60 & 0 & 60 & 27 \\
$\mathrm{~N}-\mathrm{C}-1$ & 1227 & 1113 & 113 & 1.1 \\
$\mathrm{~N}-\mathrm{C}-2$ & 903 & 820 & 82 & 1.2 \\
FeONPs/N-C-1 & 687 & 603 & 83 & 0.6 \\
Fe-N-C & 1501 & 1292 & 209 & 1.3 \\
\hline
\end{tabular}

of adsorbate uptake at low relative pressures. This suggested the presence of micropores. The specific surface area for N-C-1 was $1227 \mathrm{~m}^{2} / \mathrm{g}$ and the mean pore size was centered at $1.1 \mathrm{~nm}$ In contrast, the sample N-C synthesized by directly pyrolyzing PPy showed an ultra low specific surface area $\left(60 \mathrm{~m}^{2} / \mathrm{g}\right)$ without obvious pore structure. As depicted in Fig. 1(c), the dramatic increase in specific surface area and the generation of micropores in $\mathrm{N}-\mathrm{C}-1$, as compared with $\mathrm{N}-\mathrm{C}$, benefitted from (1) the activation of carbon via $\mathrm{Na}^{+}$reacting with the carbon to generate $\mathrm{Na}$ and gaseous $\mathrm{CO}_{2}$, and (2) the vast gaseous byproducts from the precursors during the pyrolysis. However for FeONPs/N-C-1, the specific surface area decreased significantly to $687 \mathrm{~m}^{2} / \mathrm{g}$ and the pore size decreased to $0.6 \mathrm{~nm}$, indicating FeONPs dispersed on $\mathrm{N}-\mathrm{C}-1$ residing within or covering the micropores of $\mathrm{N}-\mathrm{C}-1$ as displayed in Scheme 1. After pyrolysis of FeONPs/N-C-1, the Fe-N-C sample possessed a significantly greater specific surface area $\left(1501 \mathrm{~m}^{2} / \mathrm{g}\right)$ and a slightly larger pore size $(1.3 \mathrm{~nm})$ over that of $\mathrm{N}-\mathrm{C}-1$ (Fig. 1(b)). However, for $\mathrm{N}-\mathrm{C}-2$ derived from $\mathrm{N}-\mathrm{C}-1$, although experiencing the same thermal treatment as that of the Fe- $\mathrm{N}-\mathrm{C}$, the specific surface area was only $903 \mathrm{~m}^{2} / \mathrm{g}$ and the pore size centered at 1.2 $\mathrm{nm}$ (Fig. 1(b)). Both textural properties were significantly

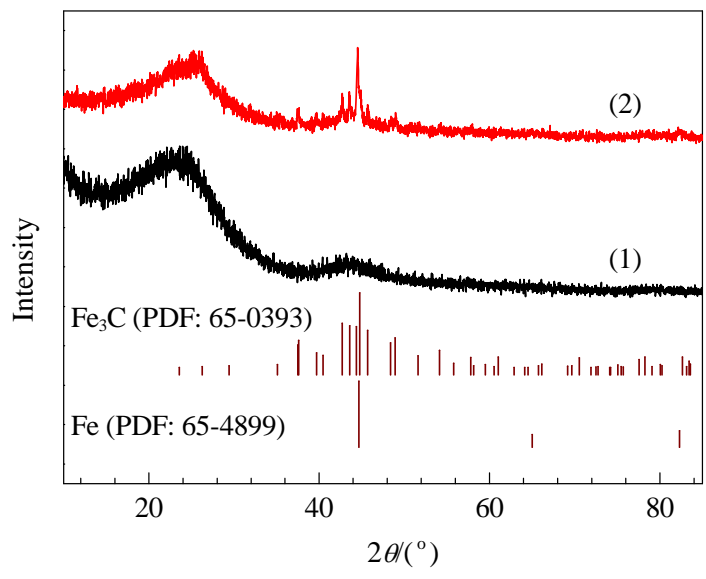

Fig. 3. XRD patterns of (1) N-C-2 and (2) Fe-N-C.

smaller than those of Fe-N-C, which suggested that FeONPs were confined by the micropores and further reacted with the active-edged nitrogen or carbon, thus enlarging the pore size, likely forming a new structure in the pores.

As shown in the SEM and TEM micrographs in Fig. 2, the Fe-N-C catalyst consisted of interconnected short carbon fibers averaging $\sim 120 \mathrm{~nm}$ (Fig. 2(c, d)). Compared with the N-C-1 (Fig. 2(a, b)), the particles in Fe-N-C displayed no significant change. Although diffraction peaks assigned to $\mathrm{Fe}$ and $\mathrm{Fe}_{3} \mathrm{C}$ were detected in the XRD patterns of the Fe-N-C catalyst (Fig. $3)$, careful observation of the Fe-N-C sample by both low resolution (Fig. 2(e)) and HRTEM (Fig. 2(f)) found no metal or metal carbide/nitride crystals. The selected area electron diffraction (SAED) showed a diffraction ring (Fig. 2(e)), instead of separated diffraction spots, which suggested a poor crystal structure of the host carbon materials. Previous reports have
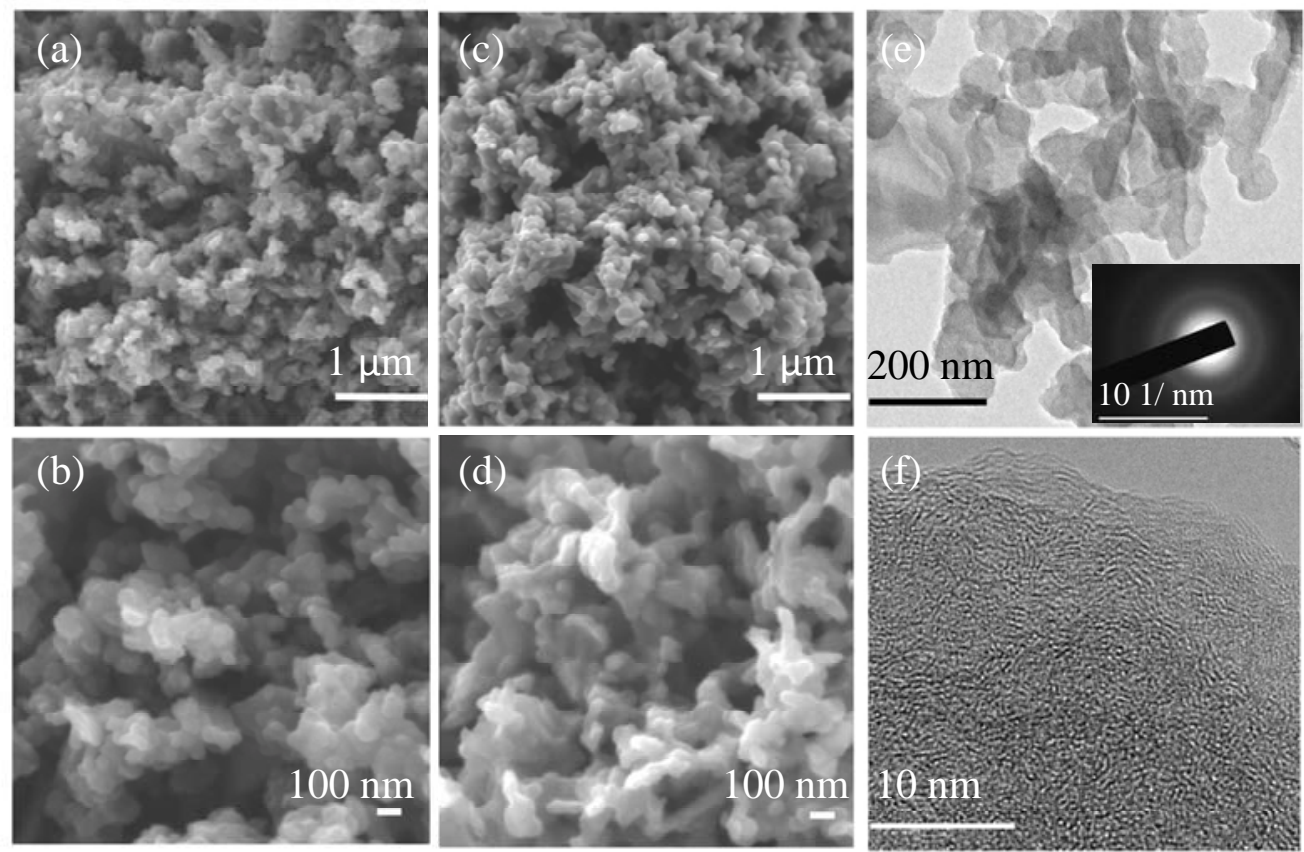

Fig. 2. SEM micrographs of N-C-1 (a, b), Fe-N-C (c, d) and TEM micrographs of Fe- $\mathrm{N}-\mathrm{C}(\mathrm{e}, \mathrm{f})$. The inset of (e) is the selected electron diffraction pattern of Fe-N-C. 
also observed inconsistencies between XRD and TEM results in similar catalysts [13].

The scanning transmission electron microscope (STEM) elemental mapping micrographs further revealed that nitrogen and iron were homogeneously distributed across the entire carbon matrix (Fig. 4). Highly dispersed iron formation may be attributed to the following factors: (1) iron was well distributed in the FeONPs/N-C-1 precursor as confirmed by elemental mapping (Fig. 5), suggesting the anchoring effect of carbon micropores on iron; (2) during the pyrolysis of FeONPs/N-C-1, the nitrogen dopants and unsaturated carbon bonds protruding from the micropores confined the iron-nitrogen/carbon reaction to a limited space and inhibited the aggregation of iron.

The chemical state of nitrogen and iron in the carbon matrix was analyzed by XPS spectroscopy (Figs. 6, 7, 8(a), Tables 2 and 3). In general, for $\mathrm{N}-\mathrm{C}, \mathrm{N}-\mathrm{C}-1, \mathrm{~N}-\mathrm{C}-2$ and $\mathrm{Fe}-\mathrm{N}-\mathrm{C}$, carbon was dominant (82.2-87.8 at\%). The nitrogen content varied from 4.9-7.2 at\% in the four samples. Fe was detected only in sample Fe-N-C at 0.5 at\%.

High resolution N 1s XPS spectra (Fig. 7(a)) were deconvoluted into five peaks according to a previous report [14], which were assigned to pyridinic-N (397.9-398.2 eV), pyrrole-N (400.6-400.8 eV), graphitic-N (401.8-402.1 eV), oxidized-N (403.1-403.5 eV) and nitrile- $\mathrm{N}$ for $\mathrm{N}-\mathrm{C}$ type catalysts or $\mathrm{Fe}-\mathrm{N}_{x}$

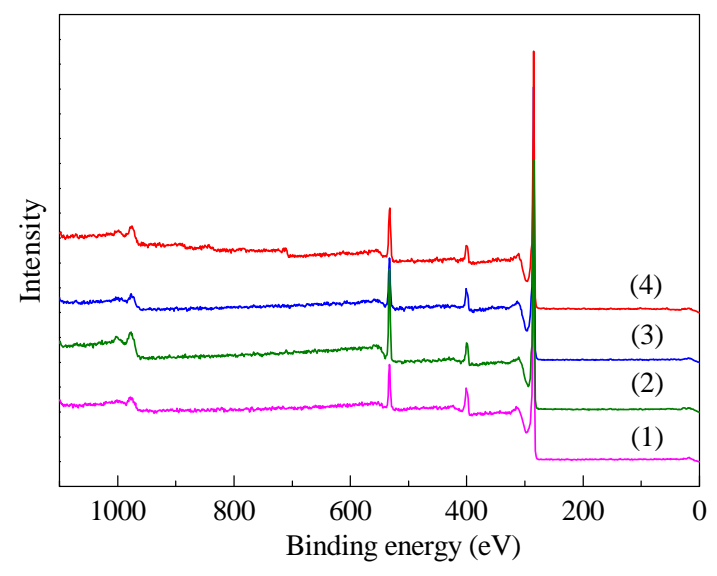

Fig. 6. XPS spectra of (1) N-C, (2) N-C-1, (3) N-C-2, and (4) Fe-N-C.

for the Fe-N-C catalyst (399.3-399.7 eV) [15,16], respectively. Together with their respective concentrations, they are listed in Table 3. To compare clearly, the contents of nitrogen type are displayed in Fig. 7(b). Interestingly, for all these samples, the sum contents of pyridinic-N and graphitic-N, which are reported to be the most active $\mathrm{N}$ species for ORR, are similar (1.99-2.92 at\%). Additionally, 0.77 at $\% \mathrm{~N}$ in the form of $\mathrm{Fe}-\mathrm{N}_{x}$
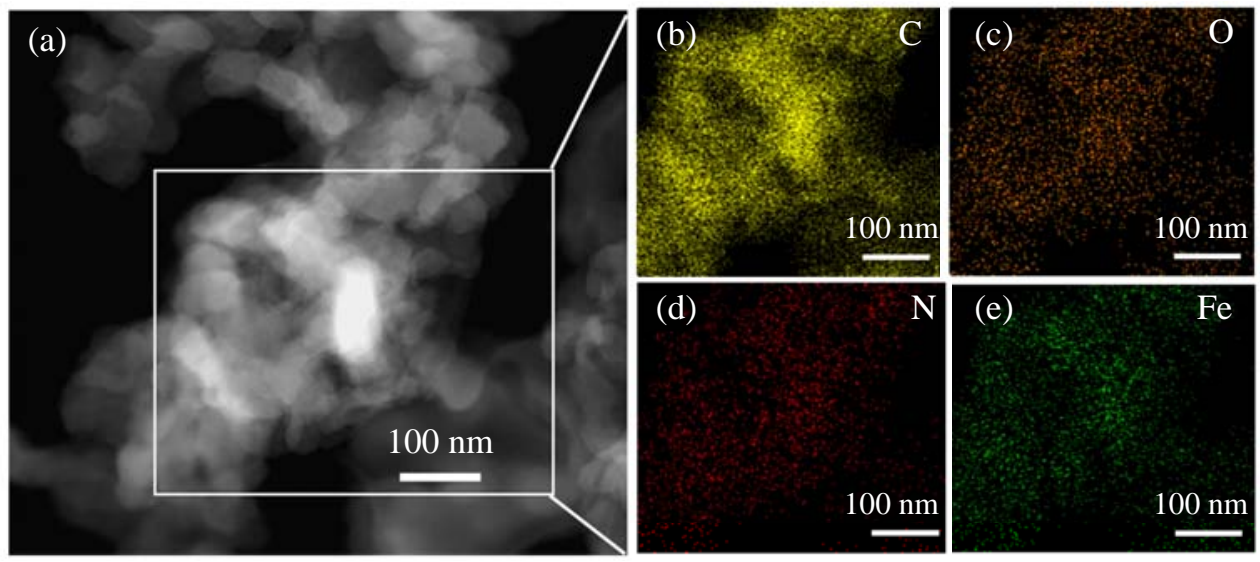

Fig. 4. (a) Scanning transmission electron microscope (STEM) micrograph of Fe- $\mathrm{N}-\mathrm{C}$ and the corresponding elemental mapping of (b) carbon, (c) oxygen, (d) nitrogen, and (e) iron in a randomly selected region.
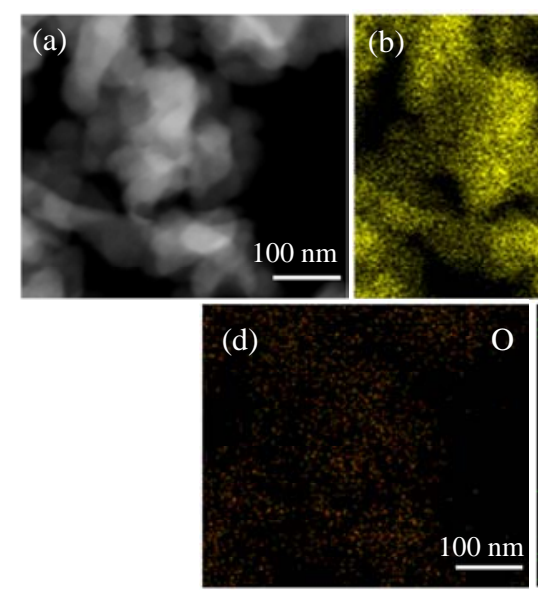
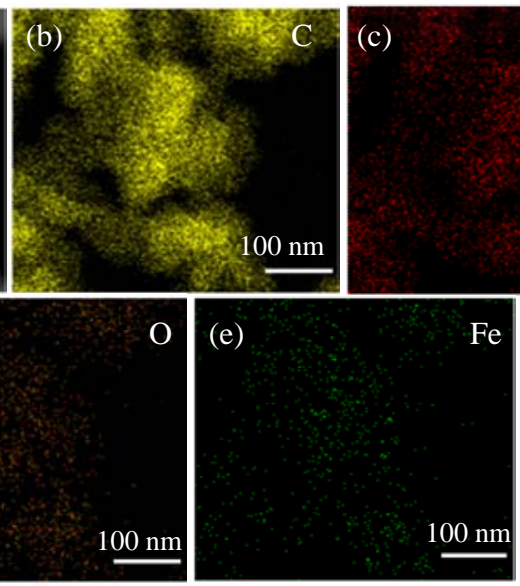

Fig. 5. (a) STEM micrograph of FeONPs/N-C-1 and the corresponding elemental mapping of (b) carbon, (c) nitrogen, (d) oxygen, and (e) iron in the selected region. 

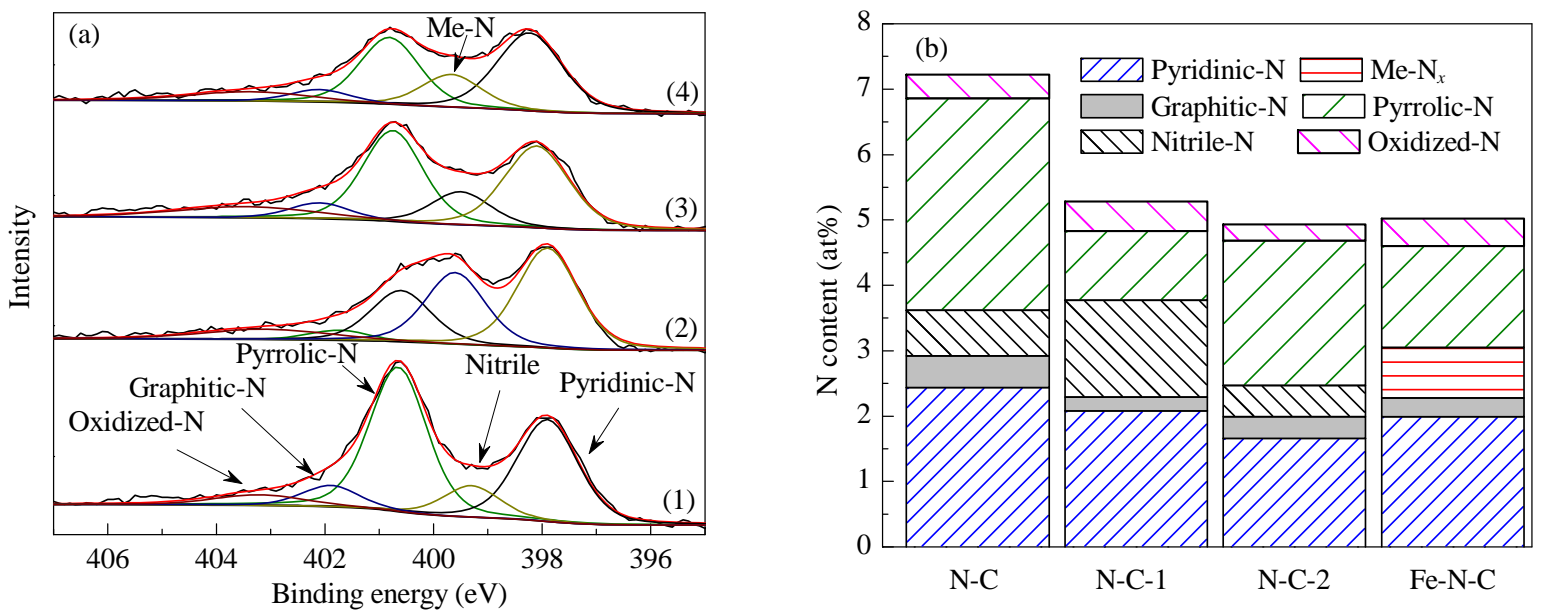

Fig. 7. (a) XPS spectra of $\mathrm{N} 1 s$ and (b) the atomic percentage of nitrogen type in the electrocatalysts. (1) N-C; (2) N-C-1; (3) N-C-2; (4) Fe-N-C.
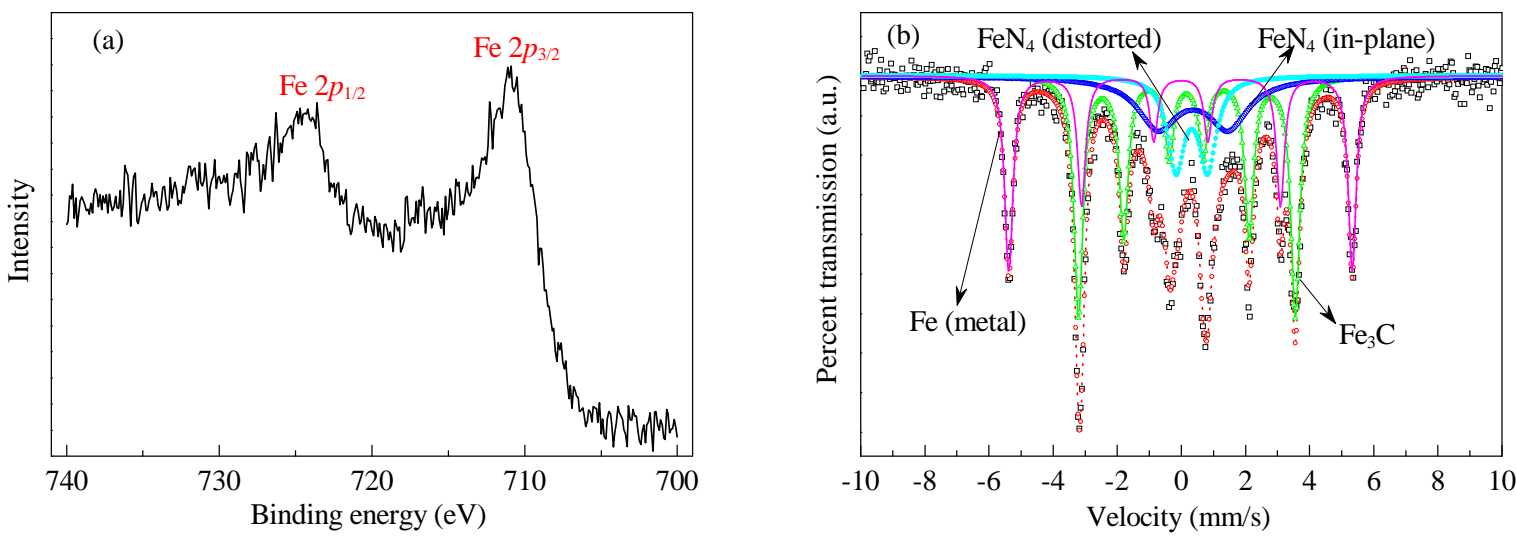

Fig. 8. (a) Fe $2 p$ XPS spectrum and (b) Mössbauer spectra of Fe-N-C.

is contained in Fe-N-C.

In the high resolution $\mathrm{Fe} 2 p$ XPS spectrum of $\mathrm{Fe}-\mathrm{N}-\mathrm{C}$, the peaks at 711.0 and $724.3 \mathrm{eV}$ (Fig. 8(a)) were assigned to $\mathrm{Fe} 2 p_{3 / 2}$ and $\mathrm{Fe} 2 p_{1 / 2}$, respectively, which corresponded to Fe(III) [16]. Thus, the iron at the surface of the Fe-N-C electrocatalyst may exist mainly in the form of a high oxidation state that coordinates with nitrogen. No signals for $\mathrm{Fe}(707 \mathrm{eV})$ and $\mathrm{Fe}_{3} \mathrm{C}(708 \mathrm{eV})$ appeared $[17,18]$, further indicating that $\mathrm{Fe}$ and $\mathrm{Fe}_{3} \mathrm{C}$ - present as characterized by XRD-may be enveloped in thick carbon layers.

Mössbauer spectroscopy is a technique based on the recoil-free absorption of $\gamma$ rays by ${ }^{57} \mathrm{Fe}$ nuclei, and is effective in investigating the electron structure of iron coordination compounds. The Mössbauer spectra of Fe-N-C is depicted in Fig. 8(b), and the related parameters summarized in Table 4. In Fig. 8(b), the two doublets in blue and cyan are assigned to $\mathrm{FeN}_{4}$

Table 2

Sample elemental composition by XPS.

\begin{tabular}{lccrc}
\hline Sample & C $1 s$ & N $1 s$ & $01 s$ & Fe $2 p$ \\
\hline N-C & 85.6 & 7.2 & 7.2 & - \\
N-C-1 & 82.2 & 5.3 & 12.6 & - \\
N-C-2 & 87.8 & 4.9 & 7.3 & - \\
Fe-N-C & 85.6 & 5.0 & 8.9 & 0.5 \\
\hline
\end{tabular}

(in-plane) and $\mathrm{FeN}_{4}$ (distorted), respectively [19]. These $\mathrm{FeN}_{4}$ structures were believed to be at the catalyst surface, as the XPS also confirmed the presence of surface $\mathrm{Fe}-\mathrm{N}_{X}$ structures. The two sextets in green and magenta correspond to $\mathrm{Fe}_{3} \mathrm{C}$ and Fe (metal), respectively [19], which is consistent with the previous XRD analysis.

Combining the analysis results of TEM, XRD, XPS and the Mössbauer spectroscopy, it is clear that the Fe-N-C sample contained highly dispersed $\mathrm{Fe}-\mathrm{N}_{4}$ units, nitrogen-doped carbon and a relatively low concentration of large $\mathrm{Fe}$ and $\mathrm{Fe}_{3} \mathrm{C}$ particles. The $\mathrm{Fe}_{\mathrm{N}} \mathrm{N}_{4}$ units and the nitrogen-doped carbon were located at the surface, while $\mathrm{Fe}$ and $\mathrm{Fe}_{3} \mathrm{C}$ particles were likely to

Table 3

Catalyst assignment of nitrogen type and respective atomic percentage.

\begin{tabular}{llccccc}
\hline & & $\begin{array}{c}\text { Pyri- } \\
\text { dinic-N }\end{array}$ & $\begin{array}{c}\text { Nitrile/ } \\
\text { Me- } N_{x}\end{array}$ & $\begin{array}{c}\text { Pyrrol- } \\
\text { ic-N }\end{array}$ & $\begin{array}{c}\text { Graphit- } \\
\text { ic-N }\end{array}$ & $\begin{array}{c}\text { Oxi- } \\
\text { dized-N }\end{array}$ \\
\hline N-C & B.E. (eV) & 397.9 & 399.3 & 400.7 & 401.9 & 403.2 \\
& Content (at\%) & 2.44 & 0.70 & 3.24 & 0.48 & 0.36 \\
\hline N-C-1 & B.E. (eV) & 397.9 & 399.6 & 400.6 & 401.8 & 403.1 \\
& Content (at\%) & 2.08 & 1.48 & 1.06 & 0.21 & 0.45 \\
\hline N-C-2 & B.E. (eV) & 398.1 & 399.5 & 400.8 & 402.1 & 403.5 \\
& Content (at\%) & 1.66 & 0.48 & 2.21 & 0.33 & 0.25 \\
\hline Fe-N-C & B.E. (eV) & 398.2 & 399.7 & 400.8 & 402.1 & 403.4 \\
& Content (at\%) & 1.99 & 0.77 & 1.55 & 0.29 & 0.42 \\
\hline
\end{tabular}


Table 4

Mössbauer parameter assignment linked to possible iron modifications.

\begin{tabular}{lcccccc}
\hline Sample & Component & $\begin{array}{c}\text { IS } \\
(\mathrm{mm} / \mathrm{s})\end{array}$ & $\begin{array}{c}\mathrm{QS} \\
(\mathrm{mm} / \mathrm{s})\end{array}$ & $\begin{array}{c}B_{h f} \\
(\mathrm{~T})\end{array}$ & $\begin{array}{c}\text { fwhm } \\
(\mathrm{mm} / \mathrm{s})\end{array}$ & $\begin{array}{c}\text { Area } \\
(\%)\end{array}$ \\
\hline Fe-N-C & $\mathrm{Fe}$ (Metal) & -0.02 & -0.01 & 33.3 & 0.30 & 28.3 \\
& $\mathrm{Fe}_{3} \mathrm{C}$ & 0.17 & 0.02 & 21.0 & 0.34 & 39.2 \\
& $\mathrm{FeN}_{4}$ (in-plane) & 0.37 & 2.19 & - & 1.58 & 18.7 \\
& $\mathrm{FeN}_{4}$ (distorted) & 0.33 & 0.99 & - & 0.64 & 13.9
\end{tabular}

IS: Isomer shift. QS: Quadrupole splitting. Bhf. Intensity of the internal magnetic field. fwhm: Full width at half maximum.

be beneath thick carbon layers because they were not detected by XPS.

The electrocatalytic activity was configured in the RRDE setup and performed in an oxygen-saturated 0.1-mol/L $\mathrm{NaOH}$ electrolyte with an electrode rotating rate of $1600 \mathrm{rpm}$ (Fig. 9(a) and (b)). As depicted in Fig. 9(a), for the N-C catalyst synthesized directly by carbonizing PPy in the absence of EDTA-2Na, the onset potential $\left(E_{0}\right)$ and the half wave potential $\left(E_{1 / 2}\right)$ were $\sim 0.87$ and $0.64 \mathrm{~V}$, respectively. $n$ varied in the range of 3.0-3.7, indicating a mixed two and four electron transfer process. For N-C-1, $E_{0}$ and $E_{1 / 2}$ shifted positively to 0.95 and $0.80 \mathrm{~V}$, respectively, and $n$ varied in the range of 3.2-4.0, suggesting significant improved catalytic activity. $E_{0}$ and $E_{1 / 2}$ values relating to the ORR polarization curve for the Fe- N-C electrocatalyst were 1.08 and $0.88 \mathrm{~V}$, respectively, which was similar to the values of the Pt/C catalyst (Fig. 9(c)). This demonstrated Fe-N-C possesses superior catalytic activity. $n$ for the
Fe-N-C catalyst approached 4, with a hydrogen peroxide yield $<3 \%$ (Fig. 9(b)), which suggested that oxygen was being electro-reduced to hydroxide via a four electron transfer process.

To understand the function of iron with respect to catalytic activity, the ORR polarization curves of the N-C-2 catalyst were also measured and compared (Fig. 9(a, b)). For N-C-2, although the catalyst was subjected to a second calcination process, similar to the Fe-N-C catalyst, not even a minor improvement in catalytic activity was observed compared with its precursor, $\mathrm{N}-\mathrm{C}-1$. Furthermore, the catalytic activity fell significantly short of the Fe-N-C catalyst (Fig. 9(a)), which implied the importance of iron for the ORR catalytic activity. Because $\mathrm{Fe}_{3} \mathrm{C}$ and $\mathrm{Fe}$ may have been beneath thick carbon layers, they could not directly participate in the catalytic process. Thus, the high catalytic activity of Fe-N-C was probably related to the surface Fe-N 4 structure based on the above XPS and Mössbauer spectra results. Additionally, the large surface area of the carbon host permitted considerable access of reagents to the active sites.

The durability of the Fe-N-C catalyst was tested via a standard accelerated aging procedure (see experimental section for details). The ORR polarization curves before and after the AAT presented a typical diffusion-controlled limiting current platform at large overpotentials (Fig. 9(c, d)). After 5000 continuous potential cycles, a negligible drop in the ORR current was observed for the Fe-N-C catalyst, while there was a 45-mV loss in $E_{1 / 2}$ for the Pt/C electrocatalyst under the same conditions (Fig. 9 (c)). From the varying trends of the $E_{1 / 2}$ during the 5000
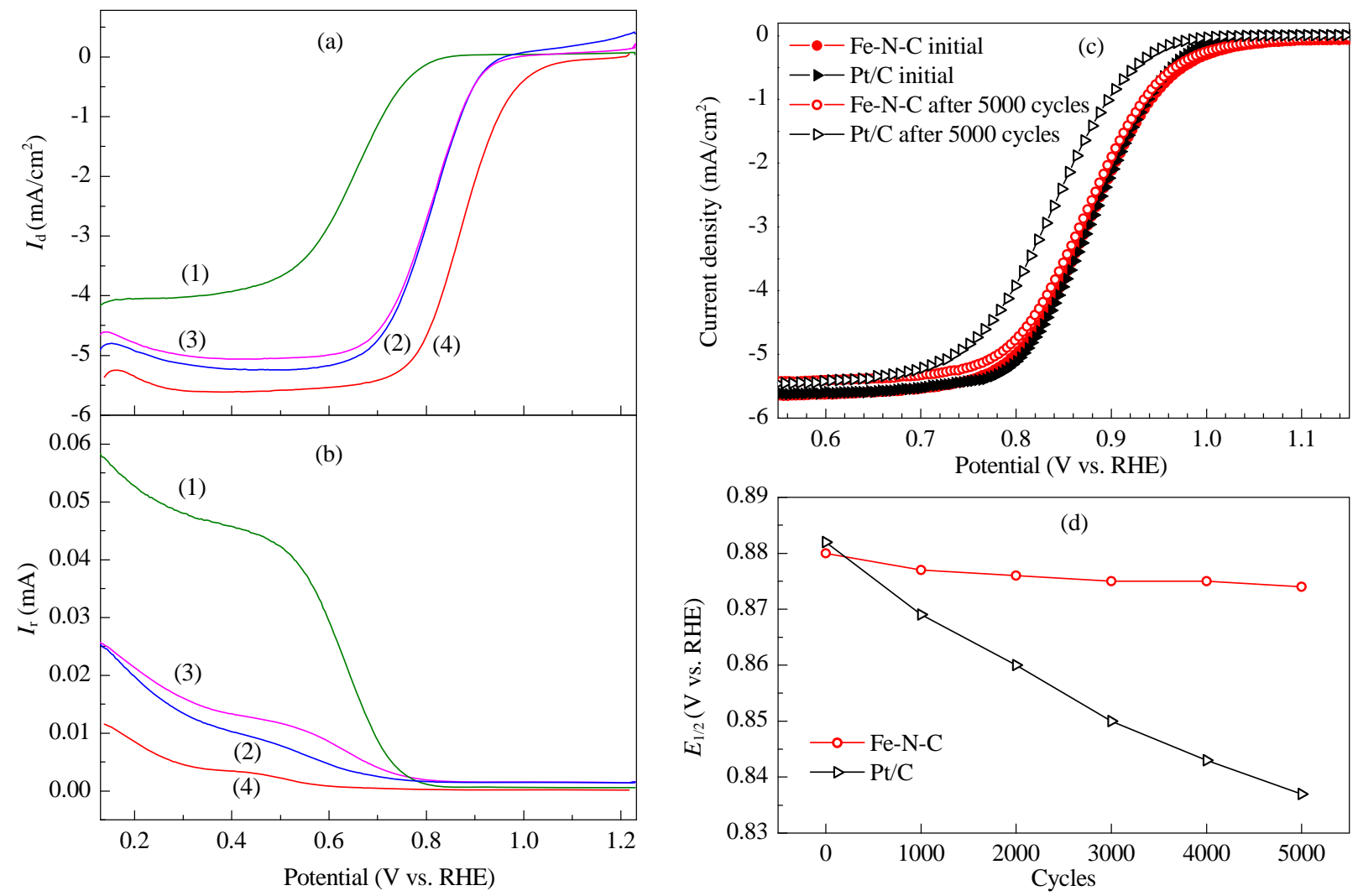

Fig. 9. ORR measurements of the electrocatalysts. (a) Disc currents; (b) Ring currents. Rotating ring disc electrode (RRDE) test conditions: $\mathrm{O}_{2}$-saturated $0.1 \mathrm{~mol} / \mathrm{L} \mathrm{NaOH}$, rotation rate $1600 \mathrm{r} / \mathrm{min}$, scan rate $10 \mathrm{mV} / \mathrm{s}$. (c) ORR polarization plots of the $\mathrm{Fe}-\mathrm{N}-\mathrm{C}\left(0.62 \mathrm{mg} / \mathrm{cm}^{2}\right) \mathrm{and} \mathrm{Pt} / \mathrm{C}(50$ $\mu \mathrm{g} / \mathrm{cm}^{2}$ ) electrocatalysts measured during 5000 cycles durability. (d) Half wave potential ( $\left.E_{1 / 2}\right)$ of Fe-N-C and Pt/C at each 1000 cycles in the durability test. (1) N-C; (2) N-C-1; (3) N-C-2; (4) Fe-N-C. 
cycling procedure (Fig. 9(d)), it was clear that the ORR activity of Pt decreased linearly, while the Fe-N-C catalyst remained relatively stable. This suggests superior durability of the Fe-N-C catalyst over that of the $\mathrm{Pt} / \mathrm{C}$ electrocatalyst in alkaline media.

Compared with $\mathrm{Pt} / \mathrm{C}$, the Fe-N-C catalyst is inert to methanol (Fig. 10(b)), a critical advantage for an effective cathodic catalyst for DMFCs [20]. The DMFC polarization curves with either Fe-N-C or a commercial Pt/C catalyst as the cathode are depicted in Fig. 10(c, d). In Fig. 10(c), with a proton exchange membrane, the maximum power density of the Fe-N-C cathode DMFC reaches up to $47 \mathrm{~mW} / \mathrm{cm}^{2}$, which is almost $60 \%$ of that for the Pt/C cathode DMFC (79 $\left.\mathrm{mW} / \mathrm{cm}^{2}\right)$. In Fig. 10(d), with the anion-exchange membranes, the maximum power density of the Fe-N-C cathode DMFC is $33 \mathrm{~mW} / \mathrm{cm}^{2}$, while the $\mathrm{Pt} / \mathrm{C}$ cathode DMFC only reaches to $8 \mathrm{~mW} / \mathrm{cm}^{2}$. There were some significant differences in the polarization curves between the Fe-N-C cathode DMFC and Pt/C cathode DMFC. (1) The open-circuit voltages (OCVs) of the Fe-N-C cathode DMFC were all higher than those with the $\mathrm{Pt} / \mathrm{C}$ cathode irrespective of the media type. This was attributed to the excellent methanol tolerance property of Fe-N-C mitigating mixed potential at the cathode [21]. (2) In the electrochemical activation polarization region shown in Fig. 10 (c, d), the Fe-N-C cathode DMFC per- formed better in alkaline media than in acidic media, which was consistent with the ORR activity of the Fe-N-C observed in the half cells (Fig. 9(a) and Fig. 10(a)). (3) In the high current density region, both Fe-N-C and Pt/C cathode DMFCs performed to a lower degree in alkaline media than in acidic media. This may indicate that the three-phase boundary required further optimization to tailor the alkaline fuel cells. However, the lower migration rate of hydroxyls when compared with protons may have degraded the performance in the high current density region. (4) In alkaline media, the polarization curve for the $\mathrm{Pt} / \mathrm{C}$ cathode DMFC dropped to a greater extent than the Fe-N-C cathode DMFC. One reason is that for $\mathrm{Pt} / \mathrm{C}$, the methanol "crossing over" from the anode would be electro-oxidized at the cathode to produce $\mathrm{CO}_{2}$, which combines with hydroxyl groups to generate carbonate salts. The local over-saturated concentration of the carbonate salts would form deposits, potentially blocking the electrode pores and impeding mass transport. This would in turn lead to the decreased performance of the Pt cathode DMFC. As for the Fe-N-C cathode, which has effective methanol tolerance, no carbonate salts would generate during the DMFC operation. The Fe-N-C cathode is therefore a promising alternative ORR catalyst over Pt in DMFC applications.
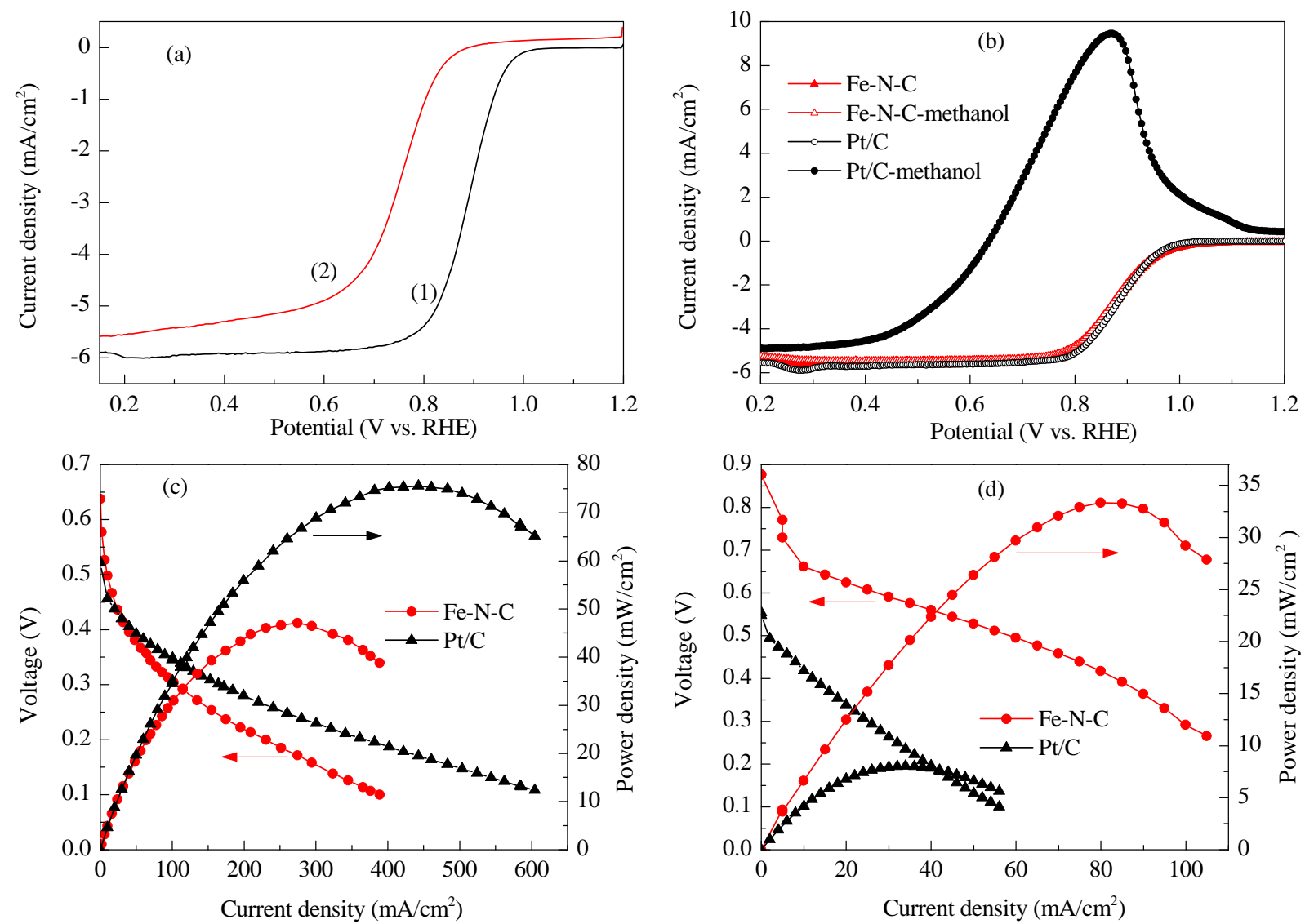

Fig. 10. (a) ORR polarization curves of (1) Pt/C and (2) Fe-N-C in $\mathrm{O}_{2}$ saturated $0.1 \mathrm{~mol} / \mathrm{L} \mathrm{HClO}{ }_{4}$ (b) ORR polarization curves of Fe- $\mathrm{N}-\mathrm{C}$ and $\mathrm{Pt} / \mathrm{C}$ in $\mathrm{O}_{2}$ saturated $0.1 \mathrm{~mol} / \mathrm{L} \mathrm{NaOH}$ in presence of methanol. (c) The acidic DMFC performance at $80{ }^{\circ} \mathrm{C}$ using Pt $/ \mathrm{C}\left(0.16 \mathrm{mg} \mathrm{Pt} / \mathrm{cm}^{2}\right)$ or Fe- $\mathrm{N}-\mathrm{C}\left(3.2 \mathrm{mg} / \mathrm{cm}^{2}\right)$ as the cathode. The anode used was PtRu black $\left(3.2 \mathrm{mg} \mathrm{PtRu} / \mathrm{cm}^{2}\right)$ with $1 \mathrm{~mol} / \mathrm{L} \mathrm{CH} \mathrm{CH}_{3} \mathrm{OH}$ supplied at a flow rate of $1 \mathrm{~mL} / \mathrm{min}$. Dry oxygen was supplied to the cathode at flow rate of $100 \mathrm{~mL} / \mathrm{min}$. (d) The alkaline DMFC performance at $80{ }^{\circ} \mathrm{C}$ with Pt $/ \mathrm{C}\left(0.12 \mathrm{mg} \mathrm{Pt} / \mathrm{cm}^{2}\right)$ or Fe-N-C $\left(3.0 \mathrm{mg} / \mathrm{cm}^{2}\right)$ used as the cathode. The anode used was PtRu black (3.0 mg PtRu/cm${ }^{2}$ ) with $2 \mathrm{~mol} / \mathrm{L} \mathrm{CH}_{3} \mathrm{OH}$ in $1 \mathrm{~mol} / \mathrm{L} \mathrm{NaOH}$ supplied at a flow rate of $1 \mathrm{~mL} / \mathrm{min}$. Dry oxygen was supplied to the cathode at a flow rate of $100 \mathrm{~mL} / \mathrm{min}$. 


\section{Conclusions}

A Fe-N-C catalyst with iron uniformly dispersed in a carbon matrix possessing a high specific surface area $\left(1501 \mathrm{~m}^{2} / \mathrm{g}\right)$ was synthesized. The catalyst exhibited excellent ORR activity in both alkaline ( $E_{0}=1.08 \mathrm{~V}$ and $E_{1 / 2}=0.88 \mathrm{~V}$ vs. RHE) and acid electrolytes ( $E_{0}=0.85 \mathrm{~V}$ and $E_{1 / 2}=0.75 \mathrm{~V}$ vs. RHE). The detailed investigation on the composition-structure-performance relationship by XRD, XPS and Mössbauer spectroscopy suggests that $\mathrm{Fe}-\mathrm{N}_{4}$, graphitic- $\mathrm{N}$ and pyridinic-N are the active components for the ORR. The DMFC employing Fe-N-C as the cathodic catalyst displayed a maximum power density of $33 \mathrm{~mW} / \mathrm{cm}^{2}$ in alkaline media (vs. $8 \mathrm{~mW} / \mathrm{cm}^{2}$ for the Pt/C cathode DMFC) and $47 \mathrm{~mW} / \mathrm{cm}^{2}$ in acidic media (vs. $79 \mathrm{~mW} / \mathrm{cm}^{2}$ for the Pt/C cathode DMFC). The promising DMFC performance is attributed to both the superior ORR activity and the effectiveness of the Fe-N-C cathode to methanol tolerance.

\section{References}

[1] M. K. Debe, Nature, 2012, 486, 43-51.

[2] R. J. Jasinski, Nature, 1964, 201, 1212-1213.

[3] M. Lefèvre, E. Proietti, F. Jaouen, J. P. Dodelet, Science, 2009, 324, 71-74.

[4] K. P. Gong, F. Du, Z. H. Xia, M. Durstock, L. M. Dai, Science, 2009, 323, 760-764.

[5] D. Banham, S. Ye, K. Pei, J. I. Ozaki, T. Kishimoto, Y. Imashiro, J. Power Sources, 2015, 285, 334-348.

[6] Z. Yang, H. G. Nie, X. A. Chen, X. H. Chen, S. M. Huang, J. Power Sources, 2013, 236, 238-249.

[7] G. Wu, K. L. More, C. M. Johnston, P. Zelenay, Science, 2011, 332, 443-447.
[8] C. W. B. Bezerra, L. Zhang, K. Lee, H. Liu, A. L. B. Marques, E. P. Marques, H. Wang, J. Zhang, Electrochim. Acta, 2008, 53, 4937-4951.

[9] J. Tian, A. Morozan, M. T. Sougrati, M. Lefèvre, R. Chenitz, J. P. Dodelet, D. Jones, F. Jaouen, Angew. Chem. Int. Ed., 2013, 125, 7005-7008.

[10] C. Baldizzone, S. Mezzavilla, H. W. P. Carvalho, J. C. Meier, A. K. Schuppert, M. Heggen, C. Galeano, J. D. Grunwaldt, F. Schüth, K. J. J. Mayrhofer, Angew. Chem. Int. Ed., 2014, 53, 1-6.

[11] C. Galeano, J. C. Meier, V. Peinecke, H. Bongard, I. Katsounaros, A. A. Topalov, A. Lu, K. J. J. Mayrhofer, F. Schuth, J. Am. Chem. Soc., 2012, 134, 20457-20465.

[12] J. Liu, L. H. Jiang, Q. W. Tang, B. S. Zhang, D. S. Su, S. L. Wang, G. Q. Sun, ChemSusChem, 2012, 5, 2315-2318.

[13] Y. S. Zhu, B. S. Zhang, X. Liu, D. W. Wang, D. S. Su, Angew. Chem. Int. Ed., 2014, 53, 10673-10677.

[14] F. Jaouen, J. Herranz, M. Lefèvre, J. P. Dodelet, U. I. Kramm, I. Herrmann, P. Bogdanoff, J. Maruyama, T. Nagaoka, A. Garsuch, J. R. Dahn, T. Olson, S. Pylypenko, P. Atanassov, E. A. Ustinov, ACS Appl. Mater. Interfaces, 2009, 1, 1623-1639.

[15] J. Zhang, D. P. He, H. Su, X. Chen, M. Pan, S. C. Mu, J. Mater. Chem. A, 2014, 2, 1242-1246.

[16] Q. Cui, S. J. Chao, P. H. Wang, Z. Y. Bai, H. Y. Yan, K. Wang, L. Yang, RSC Adv., 2014, 4, 12168-12174.

[17] X. L. Dong, Z. D. Zhang, Q. F. Xiao, X. G. Zhao, Y. C. Chuang, S. R. Jin, W. M. Sun, Z. J. Li, Z. X. Zheng, H. Yang, J. Mater. Sci., 1998, 33, 1915-1919.

[18] J. S. Zhou, H. H. Song, X. H. Chen, L. J. Zhi, J. P. Huo, B. Cheng, Chem. Mater., 2009, 21, 3730-3737.

[19] U. I. Kramm, M. Lefèvre, N. Larouche, D. Schmeisser, J. P. Dodelet, J. Am. Chem. Soc., 2013, 136, 978-985.

[20] Y. Nie, L. Li, Z. D. Wei, Chem. Soc. Rev., 2015, 44, 2168-2201.

[21] M. L. Xiao, J. B. Zhu, L. G. Feng, C. P. Liu, W. Xing, Adv. Mater., 2015, 27, 2521-2527.

\section{Graphical Abstract}

Chin. J. Catal., 2016, 37: 539-548 doi: 10.1016/S1872-2067(15)61049-X

A Fe-N-C catalyst with highly dispersed iron in carbon for oxygen reduction reaction and its application in direct methanol fuel cells

Lingzheng Gu, Luhua Jiang*, Xuning Li, Jutao Jin, Junhu Wang, Gongquan Sun*

Dalian Institute of Chemical Physics, Chinese Academy of Sciences; University of Chinese Academy of Sciences
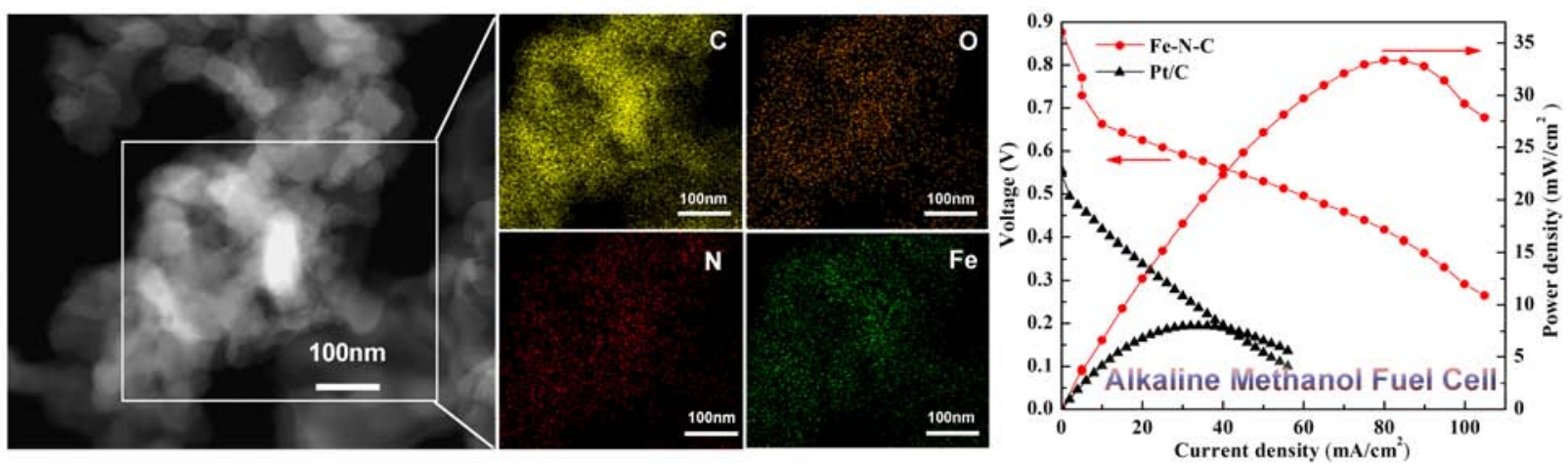

A highly dispersed Fe-N-C electrocatalyst, prepared via a two-step pyrolysis synthesis route, exhibits promising ORR activity. The Fe-N-C cathode DMFC possesses high catalytic activity together with excellent methanol tolerance properties and shows promising discharging performance. 


\title{
高分散Fe-N-C氧还原反应电催化剂及其在直接甲醇燃料电池中的应用
}

\author{
谷领峥 ${ }^{\mathrm{a}, \mathrm{c}}$ ，姜鲁华 ${ }^{\mathrm{a},{ }^{*}}$ ，李旭宁 ${ }^{\mathrm{b}, \mathrm{c}}$ ，金具涛 ${ }^{\mathrm{a}}$ ，王军虎 ${ }^{\mathrm{b}}$ ，孙公权 ${ }^{\mathrm{a}, \#}$ \\ $\mathrm{a}$ 中国科学院大连化学物理研究所, 洁净能源国家实验室燃料电池研究部, 辽宁大连116023 \\ b 中国科学院大连化学物理研究所, 穆斯堡尔谱数据中心, 辽宁大连 116023 \\ c中国科学院大学, 北京100049
}

摘要: 氧还原反应(ORR)是燃料电池和金属空气电池等洁净发电装置中阴极的主要反应, 该反应动力学过程慢, 电化学极 化严重. Pt基电催化剂具有较好的ORR活性, 然而Pt资源有限、价格昂贵, 研制高活性、低成本的代Pt电催化剂意义重大. 经 过几十年的探索, 研究者发现将含有 $\mathrm{C}, \mathrm{N}$ 和Fe等元素的前体进行高温热处理得到的Fe-N-C电催化剂对ORR 具有良好的活 性, 然而在高温热解过程中Fe容易发生聚集而形成大块颗粒, 导致Fe的利用率不高, 影响了电催化剂的ORR活性.

本文分别以聚吡咯和乙二胺四乙酸二钠(EDTA-2Na)为C和N的前驱体, 利用高温热解形成的富含微孔的碳材料对铁前 体的吸附及错定作用, 获得了一种Fe高度分散的Fe-N-C电催化剂. 采用物理吸脱附技术、高分辨透射电镜(HRTEM)和扫描 电镜对 Fe-N-C及其制备过程中相关电催化剂的孔结构及表面形貌进行了表征. 结果表明, 在第一步热解过程中, EDTA-2Na的Na对碳材料起到了活化作用, 形成富含微孔的 N掺杂碳材料(N-C-1), 其BET比表面积达到 $1227 \mathrm{~m}^{2} / \mathrm{g}$, 孔径约 $1.1 \mathrm{~nm}$. 在第二步热解过程中, N-C-1有效地抑制了 Fe的聚集, 产物Fe-N-C中的Fe元素均匀地分布在碳材料中, 其比表面积 高达 $1501 \mathrm{~m}^{2} / \mathrm{g}$.

电化学测试结果表明, 在碱性介质 $(0.1 \mathrm{~mol} / \mathrm{L} \mathrm{NaOH})$ 中, Fe-N-C电催化剂对ORR具有良好的催化活性, ORR起始电位 $\left(E_{0}\right)$ 为 $1.08 \mathrm{~V}$ (vs. RHE), 半波电位 $\left(E_{1 / 2}\right) 0.88 \mathrm{~V}$, 电子转移数 $n$ 接近 $4, \mathrm{H}_{2} \mathrm{O}_{2}$ 产率 $<3 \%$, 与商品 $20 \% \mathrm{Pt} / \mathrm{C}$ (Johnson Matthey)接近. 电化学加速老化测试结果表明, Fe-N-C的 $E_{1 / 2}$ 未发生明显变化, 而Pt的负移 $45 \mathrm{mV}$, 表明Fe-N-C具有很好的稳定性; 在酸性介 质 $\left(0.1 \mathrm{~mol} / \mathrm{L} \mathrm{HClO}_{4}\right)$ 中, Fe-N-C的 $E_{0}$ 为 $0.85 \mathrm{~V}, E_{1 / 2}$ 为 $0.75 \mathrm{~V}$, 其 $E_{1 / 2}$ 比 Pt/C负移约 $0.15 \mathrm{~V}$, 表明在酸性介质中Fe-N-C对ORR的 催化活性还有待提高. 采用TEM、X射线衍射、X射线光电子能谱以及穆斯堡尔谱等方法研究了电催化剂构效关系. 结果 表明, Fe-N-C较好的ORR活性主要来自于高分散的Fe- $\mathrm{N}_{4}$ 结构, 此外, $\mathrm{N}$ (吡啶 $\mathrm{N}$ 和石墨 $\mathrm{N}$ )掺杂的 C也对反应具有一定的催化 活性.

与 Pt/C相比, Fe-N-C电催化剂具有很好的耐甲醇性能. 本文对比了 Fe-N-C和Pt/C作为阴极催化剂的直接醇类燃料电池 (DMFC)性能, 采用质子交换膜的DMFC最大功率密度分别为47 (Fe-N-C) 和79 $\mathrm{mW} / \mathrm{cm}^{2}(\mathrm{Pt} / \mathrm{C})$, 而采用碱性电解质膜的则分 别为33(Fe-N-C)和 $8 \mathrm{~mW} / \mathrm{cm}^{2}(\mathrm{Pt} / \mathrm{C})$. 结合半电池结果表明, Fe-N-C电催化剂在碱性介质中具有比Pt更为优秀的催化活性和 稳定性, 有望用作DMFC阴极代Pt催化剂.

关键词: 高分散铁; 微孔碳材料; 氧还原反应; 直接甲醇燃料电池

收稿日期: 2016-01-07. 接受日期: 2016-01-29. 出版日期: 2016-04-05.

*通讯联系人. 电话/传真: (0411)84379063; 电子信箱: sunshine@dicp.ac.cn

\#通讯联系人. 电话/传真: (0411)84379063; 电子信箱: gqsun@dicp.ac.cn

基金来源: 中国科学院“战略性先导科技专项”(XDA09030104); 国家重点基础研究发展计划(973计划, 2012CB215500); 国家自然 科学基金(21576258, 50823008).

本文的英文电子版由Elsevier出版社在ScienceDirect上出版(http://www.sciencedirect.com/science/journal/18722067). 